Nils Moch*

\title{
The Contribution of Large Banking Institutions to Systemic Risk: What Do We Know? A Literature Review
}

https://doi.org/10.1515/roe-2018-0011

\begin{abstract}
Against the background of the global financial crisis, we review recent literature on the debate about "too big to fail". This is (still) one of the key issues in banking literature since it determines the conditions for adequate banking regulation, financial stability and economic welfare. Analyzing 30 papers from 2009 to 2017, our work focusses on the impact of large banks on systemic risk. Large financial institutions can affect systemic risk by either contributing to systemic risk or being extremely exposed to sources of systematic risk and contagion. We find a considerable number of theoretical and empirical studies providing evidence that against the background of the constitution of presentday real financial systems, bank size is a key predictor for systemic risk and that the largest banks disproportionately contribute to overall risk. This relationship is found in samples of different composition, for various periods and with different measures covering diverse aspects of systemic risk.
\end{abstract}

Keywords: financial stability, banking crises, systemic risk, too big to fail, bank bailouts

\section{Introduction}

The last global financial crisis has revitalized a well-known social, political and scientific discussion about the dangers and advantages emerging from large financial institutions for economic welfare and growth. ${ }^{1}$ As a consequence of the collapse of Lehman Brothers in September 2008, governments around the globe were forced to decide either to allow more banks to fail or to bail banks out with high social and economic costs and negative consequences for public finances. In

1 Although the discussion in general is not limited to banks and also includes, for example, insurance companies, we focus on banks only. Consequently, the term (financial) institution refers to banks or (banking) institutions interchangeably.

*Corresponding author: Nils Moch, Leuphana University Lueneburg, Institute of Finance and Accounting, Luneburg, Germany, E-mail: nils.moch@web.de 
many cases, banks were bailed out to protect creditors from substantial losses and impede further contagion into the financial system with negative impacts on the real economy (see, e. g., Molyneux, SCHAECK, and ZHOU, 2014). In those circumstances, decision makers always have to address some kind of dilemma: First, they must evaluate whether the benefits of bailing out one or more systemically important institutions to preserve financial stability outweigh the economic costs to the public sector. Second, they need to anticipate that such bailout decisions do not increase future social costs and moral hazard because private agents might interpret such a bailout policy as implicit or explicit insurance against future losses and will hence have incentives for undesirable behavior. ${ }^{2}$

In numerous cases when governments decided to bail out a certain institution, those banks in question were remarkably large in terms of total assets or in relation to their share in the national banking market. Moreover, the size of the banking sector itself in relation to the real economy has disproportionately increased in recent decades (see, e.g., BERTAY, DEMIRGÜç-Kunt, and HuIZINGA, 2013; DEMIRGÜÇ-Kunt and Huizinga, 2013; LAEven, RATnOvski, and Tong, 2016). For example, the total assets of the 50 biggest banks worldwide relative to world GDP increased from 15\% in 1970 to $83 \%$ by June 2015 (BARTH and WIHLBORG, 2016). Similarly, due to rapid technological progress (digitalization), the development of new financial products (financial innovation) and the disappearance of geographic restrictions (globalization), the size and complexity of single banking institutions have increased, and some institutions have reached dimensions that reach far beyond the national GDP of their home countries (ABREU and GULAMHUSSEN, 2013; BARTH and WiHLbORG, 2016; FREIXAS and ROCHET, 2013; JONGHE, DIEPSTRATEN, and SCHEPENS, 2015). In addition, regulators have favored the formation of even larger and more complex institutions by encouraging the acquisition of failing banks by other banking firms to limit the negative economic consequences during the crisis (BARTH and WIHLBORG, 2016; DERMINE and SCHOENMAKER, 2010; VALlASCAS and KEASEY, 2012; WALTER, 2009).

As a result of experiences in the financial crisis, banking regulation at the national and the international levels has changed in several ways and, as announced by the Leaders of the Group of Twenty (LEADERS of the GROUP of TWENTY, 2009a, 2009b), especially with regard to large financial institutions. Regulatory proposals include restrictions of bank size, structure or scope of activities as well as enhanced regulatory and supervisory requirements and procedures to reduce the cost of failures and enhance resolvability (BARTH and

2 For a specific discussion of an "optimal" decision maker's behavior see, e. g., the work of KEISTER (2016) or GONG and JonEs (2013), as this specific issue goes beyond the scope of our paper. 
Wihlborg, 2016; Bongini, Nieri, and Pelagatti, 2015; Financial Stability BOARD, 2014; GOLDSTEIN and VÉRON, 2011). Nevertheless, there also exist substantial theoretic arguments in favor of large banks since they might be able to take advantage of economies of scale (BOYD and HEITZ, 2016; MESTER, 2010) as well as increased diversification opportunities (see e. g. JONGHE, DIEPSTRATEN, and SCHEPENS, 2015; WALTER, 2009). Hence, there arises some kind of trade-off that can be expressed as follows:

Whether or not governments should bail out large institutions under any circumstances, risking moral hazard, competitive imbalances and systemic risk; restrictions on the size and scope of banks may mitigate these problems but at the cost of reducing banks' scale efficiencies and international competitiveness (INANOGLU et al., 2015, p. 113).

Along with these circumstances and questions raised to reduce the probability of future crises, we can observe a growing body of literature analyzing causes for financial crises and interrelations in global financial networks, developing new tools to measure financial risks and proposing new rules for effective banking regulation. As we will review, research has shown that the pure size of a banking institution is not a distinct indicator for its systemic relevance. However, size is still a necessary condition for systemic importance, and hence, size increases the probability for a positive bailout decision by national governments (see, e.g., ROSE and WIELADEK, 2012). Consequently, larger banking institutions face stricter regulation than their smaller counterparts in several ways.

Against this background, the aim of this paper is to provide an overview of the existing literature dealing with the contribution of large banking institutions to systemic risk. From our point of view, this question is (still) one of the key issues in banking literature since it determines the conditions for adequate banking regulation, financial stability and therefore nothing less than economic welfare. We will separate differing concepts and definitions in Section 2 before providing the classification and coding mechanism for the literature that is part of our survey sample in Section 3. In Section 4 we will review the literature and summarize our results with implications for future research in Section 5.

\section{Terminology}

\subsection{Too big to fail and related problems}

The main concern arising from the existence of large banks is that their failure "is seen as posing significant risks to other financial institutions, to the financial 
system as a whole, and possibly to the economic and social order" (STERN and FELDMAN, 2004, p. 1). In this context, during the U.S. Savings and Loans Crisis in 1984, banking regulators decided to bail out the Continental Illinois National Bank in Chicago. Unlike previous banks' failures (see KAUFMAN, 2002 for a review), this specific institution simply seemed to be too important to be closed since it was the seventh largest bank in the country at that time, having interbank relationships with more than 2,200 other banks (KAUFMAN, 2003). Further, regulators at that time had no resolution plans for any bank of size comparable to Continental Illinois. Hence, the expression of banks being "too big to fail" (TBTF) was born (KAUFMAN, 2002). Consequently, the size of a financial institution, either in absolute terms or in relation to the real economy, is a frequently used synonym for systemic importance, and there exists much literature that empirically tries to demonstrate that pure size measures are no good proxy for systemic importance (see e.g., BALLA, ERGEN, and MiguEIS, 2014; Gravelle and Li, 2013; He and Chen, 2016; LU and HU, 2014; ZHOU, 2009).

Already in 1984, the term itself was misleading since size per se was not the unique criteria for regulators' decision. In fact, a main driver to bail out Continental Illinois was the bank's interconnection to other institutions and the fear of initiating a far-reaching financial crisis due to serious contagion effects (KAUFMAN, 2003). Moreover, the number of interpretations of the term has increased over the years, and additional variations have been formulated to differentiate the causes requiring a bank bailout, such as "too systemically important to fail", "too complex to fail", "too interconnected to fail" or "too central to fail” (HE and CHEN, 2016; KAUfMAN, 2014; LU and HU, 2014). For our purpose, we adopt the definition of the Financial Stability Board for systemically important financial institutions (SIFIs), as follows: "whose disorderly failure, because of their size, complexity and systemic interconnectedness, would cause significant disruption to the wider financial system and economic activity" (FINANCIAL STABILITY BOARD, 2010, p. 1). ${ }^{3}$ We slightly modify their definition in two ways. First, we further refer to SIFIs as being banks only and hence prefer the designation as systemically important banks (SIBs) as done by the BASEl Committee on BANKING Supervision (2013). Second, we focus on

3 Very similar is the definition of the BASEL COMMITTEE ON BANKING SUPERVISION (2013), which includes size, interconnectedness, substitutability, complexity, and cross-borderactivities. 
the aspect of size although knowing that this is not a distinct indicator of systemic importance but certainly

a key measure of systemic importance [since] the larger the bank, the more difficult it is for its activities to be quickly replaced by other banks and therefore the greater the chance that its distress or failure would cause disruption to the financial markets in which it operates. The distress or failure of a large bank is also more likely to damage confidence in the financial system as a whole (BASEL COMMiTTEE ON BANKING SUPERVISION, 2013, p. 7).

Having such large banks that cannot be liquidated with common resolution processes due to concerns about financial stability implies several problems and costs that often depend on the complex interconnections in financial markets leading to possible contagion and subsequent effects. Additionally, bailing out large banks theoretically generates further social costs and moral hazard, as such a policy affects the behavior of market participants in several ways (for an extensive discussion, see, for example, STERN and FELDMAN, 2004). The existence of systemically important banks that are implicitly or explicitly deemed too big to fail distorts the competitiveness of financial markets. Market participants have less incentive to exert market discipline, which leads to a competitive advantage that is well documented in previous literature (see e. g., CuBILlas, FERnÁndEZ, and GonzÁlez, 2017; GANDHi and Lustig, 2015; MoEnNinghofF, OngEnA, and WiEANDT, 2015; NitSCHKA, 2016; UEDA and WEDER Di MAURO, 2013). Further, limited market discipline creates incentives for increased risk-taking behavior since higher profits remain private, while the risk of failure is borne by the government and taxpayers (CuBILlas, FernándeZ, and GonZÁleZ, 2017; DAM and KoETTER, 2012; Ellis, Haldane, and Moshirian, 2014; Freixas and Rochet, 2013; LAEven, RATnOvski, and Tong, 2016; Lu and Hu, 2014). Consequently, banks also have strong incentives to grow and obtain a sufficient size that enables them to make use of these advantages (BARTH and WIHLBORG, 2016; Moenninghoff, OngenA, and WieAndt, 2015; Molyneux, Schaeck, and ZHOU, 2014). This, in turn, may reduce incentives to innovate and lead to inefficient resource allocation on the firm level when banks dedicate resources to grow beyond their optimal size and operate in a cost-inefficient manner (STERN and FELdMAN, 2004; Völz and WedOw, 2011). Both is undesirable from a macroeconomic perspective because innovative capacity is a major source for economic growth and inefficient resource allocation also occurs on the macrolevel: if creditors of banks trust in government protection, they will allocate disproportionately high resources to the banking sector, which leads to inefficient growth and becomes a potential source of financial instability (INANOGLU et al., 2015; KNOT and VAN VOORDEN, 2013). This instability is long-lasting due 
to the absence of incentives to put inefficient banks out of the market (PoP and PoP, 2009)..$^{4}$

\subsection{Financial stability and the concept of systemic risk}

The issues of too big to fail and financial stability are intrinsically tied to each other. An institution, either due to its size, interconnectedness, complexity or other factors, will not be deemed too big (too interconnected, too complex, etc.) to fail if its failure will not endanger financial stability. However, finding a generally agreed definition of financial stability is a difficult task due to various existing definitions, some of which refer to the condition of financial instability. To review this discussion even briefly goes far beyond the scope of our paper, and for this purpose, we refer to the works of SMAGA (2013) or VLAHOVIĆ (2014). We adopt the definition of SMAGA (2013), who characterizes financial stability as a condition of the financial system, which is able to properly fulfill its economic functions (e.g., intermediation, liquidity transformation, capital allocation, risk transfer and pricing), limit systemic risk or macro-financial imbalances, resist internal and external shocks, restore its functions on its own and resist transfer of negative impulses within the system and between the financial system and the real economy. The fragility of financial stability and the causes of financial instability seem to have been misevaluated prior to the last financial crisis. Affected by the lessons learned from former events related to the failure of single institutions, regulatory supervision has mainly focused on the protection of private investors and depositors from losses by supervising the safety and soundness of individual banks (microprudential regulation), while the surveillance of risks regarding stability and proper functioning of the financial system as a whole (macroprudential regulation) has been circumstantial. Consequently, the lesson recently learned is that it is equally important to regulate each bank as a function of both its individual (bank-specific) risk and its joint (correlated) risk with other banks (ACHARYA, 2009).

The latter aspect refers to the concept of systemic risk, which had been addressed before the global financial crisis but which has since then become one of the most rapidly growing themes in the finance literature. Systemic risk in

\footnotetext{
4 BARTH and WiHLBorg (2016) further enumerate social costs related to what they call "regulatory capture", referring to the ability of few large banks "to have a very strong influence on regulators, supervisors and legislatives" as a result of intense lobbying efforts or financial support in elections. This view is also expressed by MulLineux (2014) who states that these banks are "simply too [...] politically influential and powerful, to serve the public good" (p. 93).
} 
the broader sense can be defined as the probability that endogenous or exogenous events or developments are of such an intensity to bring the financial system out of its desired condition capable of fostering economic welfare and growth (see, e. g., Bongini, NiERI, and PelagatTi, 2015; or Weiß, Bostandzic, and NeumanN, 2014a). For our purpose, we adapt a definition in a narrower sense and refer to systemic risk as the danger that financial problems or the default of a single financial institution may have negative externalities on the broader financial system or the real economy (BLUHM and KRAHNEN, 2014; KNOT and VAN VoORDEN, 2013; VALLASCAS and KEASEY, 2012). This definition includes the fact that systemic risk can have idiosyncratic as well as systematic components as mentioned by TARASHEV, TSATSARONIS, and BORIO (2016). Consequently, a large financial institution can affect systemic risk in two different ways. First, the institution itself could cause a negative externality to the system in case of a default and hence contribute to systemic risk. Second, an institution could be extremely exposed to sources of systematic risk, which might create second-round effects through contagion and trigger a default cascade. As it is unclear which of these possibilities is the greater threat for financial stability, our investigation will refer to both of them. Further, both types of risk should be addressed by regulators, although in different ways. While a strategy for institutions in the first group (high contribution) might be to reduce individual default risk (e. g., through higher capital buffers or increased monitoring), the second group (high exposure) may be more specifically addressed with measures to reduce their common exposure (e. g., through guidance on asset allocation or restrictions on specific business activities) (HELWEGE, 2010).

Against this background, it is obvious that systemic risk is closely related to the concept of too big to fail since a main research task is the development of measures to identify the institutions posing the major systemic risks to the financial system. We make use of this line of literature by analyzing the results provided with regard to large banks and their characteristics that increase or decrease systemic risk. A discussion of the variety of emerging techniques is not part of our paper as they are still in their infancy (LAEVEN, RATNOVSKI, and TONG, 2016). For this purpose, we refer to the work of DANIELSSON et al. (2016) or recent surveys, for example from Silva, KimurA, and Sobreiro (2017), BENOIT et al. (2017), Benoit, Colletaz, and Hurlin (2013), Bisias et al. (2012) and VANHOOSE (2011) or BANDT and HARTMANN (2000) in advance of the subprime crisis. Further, BISIAS et al. (2012) emphasize that due to the variety of aspects of systemic risk and potential transmission channels, a single measure of systemic risk might be hard to develop and probably undesirable since it is unlikely to be complete or universally applicable (ELLIS, HALDANE, and MOSHIRIAN, 2014). 


\section{Classification of literature}

To provide an overview of the literature included in our survey, we follow the method used by SILVA, KIMURA, and SOBREIRO (2017) and implement a classification scheme with various dimensions coded with numbers and letters. For this purpose, we apply the following categories and specifications to the 30 articles included in our survey and further show their distribution in the sample in Table 1.

Table 1: Classification and coding used to analyze the articles in sample.

\begin{tabular}{|c|c|c|c|}
\hline Category & Meaning & Encryption & $\begin{array}{r}\text { Sample } \\
\text { distribution }\end{array}$ \\
\hline 1 & Type of study & $\begin{array}{l}\text { A - Theoretical } \\
\text { B - Empirical } \\
\text { C - Both }\end{array}$ & $\begin{array}{r}7(23 \%) \\
22(73 \%) \\
1(3 \%)\end{array}$ \\
\hline 2 & Approach & $\begin{array}{l}\text { A - Quantitative } \\
\text { B - Qualitative }\end{array}$ & $\begin{array}{r}28(93 \%) \\
2(7 \%)\end{array}$ \\
\hline 3 & Scope & $\begin{array}{l}\text { A - One country } \\
\text { B - Region } \\
\text { C - World } \\
\text { D - Not specified }\end{array}$ & $\begin{array}{l}9(30 \%) \\
5(17 \%) \\
9(30 \%) \\
7(23 \%)\end{array}$ \\
\hline 4 & Context & $\begin{array}{l}\text { A - Developed country } \\
\text { B - Mixed } \\
\text { C - Not specified }\end{array}$ & $\begin{aligned} 15 & (50 \%) \\
7 & (23 \%) \\
8 & (27 \%)\end{aligned}$ \\
\hline 5 & Type of bank & $\begin{array}{l}\text { A - Commercial banks } \\
\text { B - Mixed } \\
\text { C - Not specified }\end{array}$ & $\begin{array}{r}6(20 \%) \\
9(30 \%) \\
15(50 \%)\end{array}$ \\
\hline 6 & Studied periods & $\begin{array}{l}\text { A - Up to } 2 \text { years } \\
\text { B - From } 2 \text { to } 5 \text { years } \\
\text { C - From } 5 \text { to } 10 \text { years } \\
\text { D - More than } 10 \text { years } \\
\text { E - Not specified }\end{array}$ & $\begin{array}{r}3(10 \%) \\
2(7 \%) \\
2(7 \%) \\
17(57 \%) \\
6(20 \%)\end{array}$ \\
\hline 7 & $\begin{array}{l}\text { Results: "With respect to } \\
\text { systemic risk, bank size ... }\end{array}$ & $\begin{array}{l}\text { A }-\ldots \text { is a major determinant" } \\
\text { B }-\ldots \text { is not significant" } \\
\text { C }-. . . \text { is a major determinant under } \\
\text { certain conditions" }\end{array}$ & $\begin{array}{r}16(53 \%) \\
5(17 \%) \\
9(30 \%)\end{array}$ \\
\hline
\end{tabular}

Table 2 offers a complete overview of the reviewed articles and the application of the coding mechanism to each study. We particularly focused our sample on the literature that emerged during or after the last global financial crisis, of which more than $85 \%$ was published after 2011. Further, through the combination of 
Table 2: Articles in sample.

\begin{tabular}{|c|c|c|c|c|c|c|c|}
\hline Study & Type & Approach & Scope & Context & Bank & Periods & Results \\
\hline ACHARYA et al. (2017) & $1 \mathrm{~B}$ & $2 \mathrm{~A}$ & $3 A$ & $4 \mathrm{~A}$ & $5 B$ & $6 \mathrm{~A}$ & $7 \mathrm{~A}$ \\
\hline $\begin{array}{l}\text { ADRIAN and } \\
\text { BRUNNERMEIER (2016) }\end{array}$ & 1B & $2 \mathrm{~A}$ & $3 \mathrm{~A}$ & $4 \mathrm{~A}$ & $5 B$ & $6 \mathrm{D}$ & $7 \mathrm{~A}$ \\
\hline $\begin{array}{l}\text { ARINAMINPATHY, KAPADIA, } \\
\text { and MAY (2012) }\end{array}$ & $1 \mathrm{~A}$ & $2 \mathrm{~A}$ & $3 D$ & $4 C$ & $5 C$ & $6 \mathrm{E}$ & $7 \mathrm{C}$ \\
\hline $\begin{array}{l}\text { BALLA, ERGEN, and } \\
\text { MIGUEIS (2014) }\end{array}$ & 1B & $2 \mathrm{~A}$ & $3 A$ & $4 \mathrm{~A}$ & $5 A$ & $6 \mathrm{D}$ & $7 \mathrm{~A}$ \\
\hline $\begin{array}{l}\text { BANULESCU and } \\
\text { DUMITRESCU (2015) }\end{array}$ & 1B & $2 \mathrm{~A}$ & $3 A$ & $4 \mathrm{~A}$ & $5 B$ & $6 \mathrm{D}$ & $7 \mathrm{~A}$ \\
\hline BATTISTON et al. (2012) & $1 \mathrm{~A}$ & $2 \mathrm{~A}$ & $3 D$ & $4 C$ & $5 C$ & $6 \mathrm{E}$ & $7 C$ \\
\hline $\begin{array}{l}\text { BRUNNERMEIER, DONG, } \\
\text { and PALIA (2012) }\end{array}$ & 1B & $2 \mathrm{~A}$ & $3 A$ & $4 \mathrm{~A}$ & $5 A$ & $6 \mathrm{D}$ & $7 \mathrm{~A}$ \\
\hline $\begin{array}{l}\text { BUCH, KRAUSE, and } \\
\text { TONZER }(2017)\end{array}$ & 1B & $2 \mathrm{~A}$ & $3 B$ & $4 \mathrm{~A}$ & $5 C$ & $6 \mathrm{D}$ & $7 \mathrm{~A}$ \\
\hline $\begin{array}{l}\text { CACCIOLI, CATANACH, and } \\
\text { FARMER (2012) }\end{array}$ & $1 \mathrm{~A}$ & $2 \mathrm{~A}$ & $3 D$ & $4 C$ & $5 C$ & $6 \mathrm{E}$ & $7 C$ \\
\hline $\begin{array}{l}\text { CASTRO and FERRARI } \\
(2014)\end{array}$ & $1 \mathrm{~B}$ & $2 \mathrm{~A}$ & $3 B$ & $4 \mathrm{~A}$ & $5 C$ & $6 \mathrm{D}$ & $7 \mathrm{~A}$ \\
\hline GRAVELLE and LI (2013) & $1 \mathrm{~B}$ & $2 \mathrm{~A}$ & $3 \mathrm{~A}$ & $4 \mathrm{~A}$ & $5 B$ & $6 \mathrm{D}$ & $7 \mathrm{~B}$ \\
\hline $\begin{array}{l}\text { HOVAKIMIAN, KANE, and } \\
\text { LAEVEN (2012) }\end{array}$ & 1B & $2 \mathrm{~A}$ & $3 A$ & $4 \mathrm{~A}$ & $5 A$ & $6 \mathrm{D}$ & $7 \mathrm{~A}$ \\
\hline $\begin{array}{l}\text { HUANG, ZHOU, and ZHU } \\
\text { (2012) }\end{array}$ & 1B & $2 \mathrm{~A}$ & $3 B$ & 4B & $5 C$ & $6 \mathrm{~B}$ & $7 \mathrm{~A}$ \\
\hline JONGHE (2010) & $1 \mathrm{~B}$ & $2 \mathrm{~A}$ & $3 B$ & $4 \mathrm{~A}$ & $5 B$ & $6 \mathrm{D}$ & $7 \mathrm{~A}$ \\
\hline $\begin{array}{l}\text { JONGHE, DIEPSTRATEN, and } \\
\text { SCHEPENS (2015) }\end{array}$ & 1B & $2 \mathrm{~A}$ & $3 C$ & $4 C$ & $5 B$ & $6 \mathrm{D}$ & $7 C$ \\
\hline KNAUP and WAGNER (2010) & 1B & $2 \mathrm{~A}$ & $3 \mathrm{~A}$ & $4 \mathrm{~A}$ & $5 A$ & $6 \mathrm{~B}$ & $7 \mathrm{~B}$ \\
\hline $\begin{array}{l}\text { KRAUSE and GIANSANTE } \\
\text { (2012) }\end{array}$ & $1 \mathrm{~A}$ & $2 \mathrm{~A}$ & $3 D$ & $4 C$ & $5 C$ & $6 \mathrm{E}$ & $7 C$ \\
\hline $\begin{array}{l}\text { LAEVEN, RATNOVSKI, and } \\
\text { TONG (2014) }\end{array}$ & 1B & $2 \mathrm{~A}$ & $3 C$ & 4B & $5 B$ & $6 \mathrm{D}$ & $7 \mathrm{~A}$ \\
\hline $\begin{array}{l}\text { LAEVEN, RATNOVSKI, and } \\
\text { TONG (2016) }\end{array}$ & 1B & $2 \mathrm{~A}$ & $3 C$ & 4B & $5 B$ & $6 \mathrm{~A}$ & $7 \mathrm{~A}$ \\
\hline $\begin{array}{l}\text { LÓPEZ-ESPINOSA et al. } \\
\qquad(2012)\end{array}$ & 1B & $2 \mathrm{~A}$ & $3 C$ & $4 \mathrm{~A}$ & $5 C$ & $6 C$ & $7 \mathrm{~B}$ \\
\hline $\begin{array}{l}\text { LÓPEZ-ESPINOSA et al. } \\
\text { (2013) }\end{array}$ & 1B & $2 \mathrm{~A}$ & $3 C$ & $4 \mathrm{~A}$ & $5 C$ & $6 C$ & $7 \mathrm{~B}$ \\
\hline Lu and Hu (2014) & $1 \mathrm{~A}$ & $2 B$ & $3 D$ & $4 C$ & $5 C$ & $6 \mathrm{E}$ & $7 C$ \\
\hline PAIS and STORK (2013) & 1B & $2 \mathrm{~A}$ & $3 C$ & $4 B$ & $5 C$ & $6 \mathrm{D}$ & $7 \mathrm{~A}$ \\
\hline $\begin{array}{l}\text { PUZANOVA and DÜLLMANN } \\
\text { (2013) }\end{array}$ & 1B & $2 \mathrm{~A}$ & $3 C$ & 4B & $5 \mathrm{~A}$ & $6 \mathrm{D}$ & $7 \mathrm{~A}$ \\
\hline
\end{tabular}


Table 2: (continued)

\begin{tabular}{|c|c|c|c|c|c|c|c|}
\hline Study & Type & Approach & Scope & Context & Bank & Periods & Results \\
\hline $\begin{array}{l}\text { TARASHEV, TSATSARONIS, } \\
\text { and BORIO (2016) }\end{array}$ & $1 C$ & $2 \mathrm{~A}$ & $3 D$ & $4 C$ & $5 C$ & $6 \mathrm{~A}$ & $7 \mathrm{~A}$ \\
\hline $\begin{array}{l}\text { VALLASCAS and KEASEY } \\
\text { (2012) }\end{array}$ & $1 \mathrm{~B}$ & $2 \mathrm{~A}$ & $3 B$ & $4 \mathrm{~A}$ & $5 A$ & $6 \mathrm{D}$ & $7 A$ \\
\hline WAGNER (2010) & $1 \mathrm{~A}$ & $2 \mathrm{~B}$ & $3 D$ & $4 C$ & $5 C$ & $6 \mathrm{E}$ & $7 C$ \\
\hline $\begin{array}{l}\text { WEIß, BOSTANDZIC, and } \\
\text { NEUMANN (2014a) }\end{array}$ & $1 \mathrm{~B}$ & $2 \mathrm{~A}$ & $3 C$ & $4 B$ & $5 B$ & $6 \mathrm{D}$ & $7 C$ \\
\hline $\begin{array}{l}\text { WeIß, NeUmANN, and } \\
\text { BostandzIC (2014b) }\end{array}$ & 1B & $2 \mathrm{~A}$ & $3 C$ & $4 \mathrm{~B}$ & $5 C$ & $6 \mathrm{D}$ & $7 C$ \\
\hline ZноU (2009) & $1 \mathrm{~A}$ & $2 \mathrm{~A}$ & $3 A$ & $4 \mathrm{~A}$ & $5 C$ & $6 \mathrm{D}$ & $7 \mathrm{~B}$ \\
\hline
\end{tabular}

different categories, we are able to provide more detailed information on connections or dependencies among different aspects and results. For example, reviewing the combined classifications of category 1 ("Type of study") and category 7 ("Results") reveals interesting aspects regarding our primary research question. Specifically, we observe that none of the theoretical studies (1A) finds that bank size is per se a major determinant for systemic risk (7A), as the combination of $1 \mathrm{~A}$ and $7 \mathrm{~A}$ does not exist. Conversely, the combination of $1 \mathrm{~B}$ and 7A appears sixteen times, meaning that the majority of empirical evidence finds size to be a major determinant for systemic risk. Additionally, we observed that among these sixteen empirical studies, twelve studies cover a long observation period or more than ten years (joint appearance of $1 \mathrm{~B}, 6 \mathrm{D}$ and $7 \mathrm{~A}$ ).

\section{Is size per se a relevant determinant for systemic risk?}

Recently, many studies have investigated the relationship between an institution's individual exposure to system-wide crises or its contribution to systemic risk due to size and connectivity. These works reveal the theory regarding the advantages of diversification in a different light. The assumption that the systemic importance of a particular bank is closely associated with the variety of risky banking activities in which it participates, leads to "a tradeoff between managing individual risk and keeping independency from the entire banking system" (ZHOU, 2009, p. 20). Since it is reasonable to assume that large banks are typically more diversified, BAELE, JONGHE, and VANDER VENNET (2007) 
already mentioned that larger banks are more exposed to market-wide events and systematic risk. They decompose total bank risk into a systematic and an idiosyncratic component and find that diversified banks have a higher systematic risk as they are more exposed to market volatility. Further, BAELE, JONGHE, and VANDER VENNET (2007) find that the exposure of those banks to systematic risk increases with size and even dominates positive effects on idiosyncratic risk so that, overall, pure size and bank total risk are positively correlated. In other words, while diversification can reduce a bank's idiosyncratic risk, it may increase exposure to systematic risk. From a systemic perspective, it could therefore be desirable to have large but isolated banks, whereas large banks that diversify banking activities, probably to reduce their idiosyncratic risk, may become a threat for financial stability.

We will review the recent literature regarding the contribution of large banking institutions to systemic risk in three different subsections. First, we will refer to works that address this issue theoretically or by using network simulation models. Second, we consider empirical works using a variety of heterogeneous measures before taking a closer look on empirical works that rely on more homogenous techniques which appear to evolve as a common standard in this area of research.

\subsection{Theoretical evidence on systemic risk based on the architecture of the financial system}

ZHOU (2009) creates an artificial banking system to distinguish size from systemic importance. Theoretically, ZHOU (2009) agrees that a large bank that is more diversified may become systemically important. In a second step, this researcher investigates systemic importance with three different measures ${ }^{5}$ based on daily equity returns of 27 US banks before checking the correlation with various bank size parameters. He finds that for his sample, the systemic importance measures are not correlated with the size measures and concludes that size per se is no valid indicator for the contribution to systemic risk. Against this background, WAGNER (2010) presents a model with two banks to illustrate

5 In particular, they use the PAO ("probability that at least one bank becomes distressed") measure introduced by SEGOVIANO and GODDHART (2009) and two new measures they propose, namely the "systemic importance index" (SII) measuring the expected number of bank failures in the banking system given that one particular bank fails and the "vulnerability index" (VI) reflecting the probability of a particular bank's failure given that there exists at least one another failure in the system. 
theoretically that diversification makes systemic crises more likely, since it exposes banks to the same idiosyncratic risk of jointly held assets. This author concludes that perfect diversification is always inefficient from a systemic perspective, while an arbitrary low amount is always desirable. It is important to mention that the adverse effects of diversification are even higher when contagious spillovers (e. g., bank runs on solvent banks due to solvency problems at other banks) occur. This result is also found by BATTISTON et al. (2012), who use a theoretical model to explore the dynamics of default cascades in a network of credit interlinkages. LU and HU (2014) further analyze the relationship between size and systemic risk by constructing a theoretical model with three banks (large, medium, and small) in the financial system. These researchers find that size is an important but not the dominant factor for systemic importance, which is also affected by the interconnection of banks. In other words, systemic importance must not follow the size of a bank, but below a certain size, systemic importance is difficult to achieve.

To develop these thoughts further, we consider the works of ARINAMINPATHY, KAPAdia, and MAy (2012), CACCioli, CATANACH, and FARMER (2012) and KRAUSE and GIANSANTE (2012), who use network models to examine financial stability in a systemic perspective. CACCIOLI, CATANACH, and FARMER (2012) use a model of contagion in financial networks and study how the stability of a system is affected by the size distribution of banks inside the network. Their results show that the contribution of large banks to systemic risk or the risk of size per se for financial stability is conditional on the properties of the system. While in slightly connected systems, highly connected banks (too interconnected to fail) are a greater threat for financial stability, in systems with a high degree of connectivity, size is clearly more dangerous (too big to fail). The rationale here is that, in the case of a loosely connected banking system, the failure of a large bank would only affect a few other banks with finite potential for system-wide contagion, while the failure of a highly connected bank whose interbank liabilities are spread to many other (loosely connected) banks would be contagious since those banks make less use of risk sharing opportunities and will hence share many of their interbank assets with the failed bank. On the other hand, in a highly interconnected system, the existence of large banks may imply that the assets within the banking system are non-uniformly distributed and that larger banks receive a disproportionately high share of assets from their creditors. Thus, the failure of a small (highly connected) bank would not endanger financial stability, whereas the failure of a large bank would have disproportionately adverse effects on numerous banks, which are in turn interconnected and may trigger a default cascade that turns into a financial crisis. Consequently, since financial markets today are generally highly interconnected networks, CACCIOLI, CATANACH, and FARMER (2012) conclude that the 
largest banks in this network pose a risk for financial stability simply due to their asset size. A similar investigation is made by KRAUSE and GIANSANTE (2012), who find quite similar results. First, for a strong banking system that is shocked by the collapse of a single bank, they find that the larger the bank is, the more likely and widespread a banking crisis will be on average. The rationale behind this is again that larger banks typically have more connections and their interbank loans granted and taken are larger. Second, once contagion occurs through the initial failure of a large bank, the topology of the financial network, e. g., the interconnectedness of the interbank loan network, is an equally important determinant of systemic risk as also found by BATTISTON et al. (2012). ARINAMINPATHY, KAPADIA, and MAY (2012) also use a dynamic network model of a banking system and complement the works of CACCIOLI, CATANACH, and FARMER (2012) and KRAUSE and GIANSANTE (2012) by integrating different transmission channels of contagion among banks as well as confidence effects linked to capital and liquidity strength of banks. Their simulations yield several important results. First, allowing for liquidity hoarding and asset price contagion, as seen during the last crisis, disproportionately increases the risk pure size poses to financial stability. Second, similar to CACCIOLI, CATANACH, and FARMER (2012), they also observe an asymmetry regarding the stabilizing effects of additional capital buffers that are more effective in mitigating contagion when exercised on large banks. Third, in highly concentrated banking systems where the largest banks are several times the size of small banks, this disparity is amplified. Finally, ARINAMINPATHY, KAPADIA, and MAY (2012) confirm the results of BAELE, JONGHE, and VANDER VENNET (2007), WAGNER (2010) and BATTISTON et al. (2012) by finding that diversification in fact lowers individual bank risk but clearly increases systemic risk since it exacerbates the potential for asset contagion to cause a system collapse.

Thus, as an intermediate result, we note that none of the aforementioned theoretical studies provides a line of reasoning to assume that banks, solely due to their size, are a threat to financial stability. This result is indeed little surprising because reducing "too big to fail" to a single aspect, asset size in this case, inevitably oversimplifies this issue against the background of the complexity and economic interconnections of present day global financial markets. However, from a theoretical perspective, nearly all reviewed studies, with ZHOU (2009) being the only exception, find that under several surrounding conditions and properties of the financial system, size is one of the most important factors for systemic risk. First, in systems with a high degree of connectivity, size is clearly more dangerous, and allowing for liquidity hoarding and asset price contagion disproportionately increases the risk pure size poses to financial stability. Second, contagious spillovers also increase the adverse effects of diversification and large banks that diversify their activities make 
systemic crises more likely, since they are exposed to multiple idiosyncratic risks and exacerbate the potential for a system collapse. Furthermore, systemic risk arising from the existence of (very) large banks is supposed to scale more than proportionately with size.

\subsection{Empirical evidence based on a variety of heterogeneous systemic risk measures}

TARASHEV, TSATSARONIS, and BORIO (2016) empirically verify the previous results obtained from network models. They use the Shapley Value, a concept well-known in game theory, to allocate system-wide risk to individual institutions. It represents the change in the risk of a financial system that is due to the inclusion (exclusion) of a specific bank into the system (out of the system). They demonstrate for a sample of 60 large banks by the end of 2007 as well as for a hypothetical banking system that size is by far the most important determinant of systemic importance. Further, an increase in bank size disproportionately increases the contribution of a particular institution to systemic risk.

PUZANOVA and DÜLLMANN (2013) apply a credit portfolio model to measure systemic risk and each institution's individual contribution to it for a portfolio of the world's largest commercial banks from 1997 to 2010. They find that in the time dimension, an individual bank's systemic risk contribution is not sensitive to changes in relative bank size. In contrast, at a given point in time and with a given level of systemic risk, the risk allocation among the banks in the banking system is to a large extent driven by the banks' relative size. The largest banks in the sample always disproportionately contribute to overall risk, a result that is again consistent with the findings of ARINAMINPATHY, KAPADIA, and MAY (2012) and TARASHEV, TSATSARONIS, and BORIO (2016). Unfortunately, PUZANOVA and DÜLLMANN (2013) do not explicitly investigate whether these findings must be attributed simply to the pure (relative) size of banks or whether there are other observable (or even unobservable) individual bank characteristics that yield these results. Regardless, they note an important observation in this context that is in line with previous studies, namely, that it is not only individual characteristics that affect the systemic importance of a bank, but the characteristics of the system itself do, as well (e.g., the size of other banks, default probabilities or return correlations). Hence, they conclude that regulatory instruments concentrating simply on the size of banks would inadequately address systemic risk which should necessarily be analyzed in a portfolio context.

This portfolio aspect is addressed by market-based systemic risk measures. A common feature of most systemic risk measures is that they rely on public market 
data, such as asset prices or CDS premiums. They typically consider an aggregate risk measure for the whole system, and the systemic risk analysis is closely related to portfolio theory in the sense that each institution within a financial system partly contributes to overall risk (BANULESCU and DUMITRESCU, 2015).

According to the results of JONGHE (2010), the absolute size of a bank is a main driver of individual bank systemic risk under adverse economic conditions and seems to play a vital role in determining the exposure to shocks. For a sample of listed European commercial banks and bank holding companies from 1992 to 2007, the author measures systemic risk by estimating a bank's tail beta, which equals the probability of extreme stock price devaluations conditional on a crash in the market index. He finds that larger banks appear to be in a worse position than smaller banks. None of the observed bank-specific control variables contributes more to bank-specific exposure to an extreme market downturn. This positive correlation is further corroborated by an additional dummy variable for large and complex banking groups. Further, JonGHE (2010) finds that banks focusing on traditional lending activities are less exposed to systemic risk than diversified banks shifting to non-traditional business, especially to trading activities. KNAUP and WAGNER (2010) propose a forward-looking measure of a bank's exposure to systemic risk, as they estimate share price sensitivities to changes in far out-of-the-money put option prices. Similar to JoNGHE (2010), they find that traditional banking activities lower the exposure to systemic risk, while for trading activities the opposite holds. Contrary to JONGHE (2010), they find that systemic risk exposure decreases with size, which could be caused by sample selection and chosen time period or more likely by several methodological differences. First, they consider a large prolonged market downturn instead of daily crashes induced by a systemic shock. Second, their systemic risk measure identifies changes in perceived exposures to a hypothetical crash, while other market-based measures rely on realized historical price developments. This, in turn, makes their measure susceptible to too big to fail distortions and might explain why they find a negative influence of bank size on systemic risk exposure. HovAKIMIAN, KANE, and LAEVEN (2012) use a long period of stock market data from 1974 to 2010 for a sample similar to that of KNAUP and WAGNER (2010) to measure the fragility of the banking sector as the value of a put option insuring the aggregate assets of a portfolio of banks and each bank's systemic risk as its individual contribution to this insurance premium. Contrary to KNAUP and WAGNER (2010), they find that size is a key driver of systemic risk, as an individual bank's contribution increases with size, and the largest banks in the sample represent the main source of systemic risk.

These results are confirmed by the work of PAIS and STORK (2013), who find that size is not a relevant driver of individual bank risk (measured as the 
probability of large negative stock returns) but that large banks have significantly higher systemic risk (measured as the probability of a simultaneous crash in stock prices) and that this relationship is non-linear. Further, this effect increases along with financial market integration since it amplifies the common exposure to market-wide risks. HUANG, ZHOU, and ZHU (2012) verify these results for a sample of 22 banks in the Asia-Pacific region. Although using a different systemic risk measure, they find that bank size is the primary factor in determining the contribution of a single institution to systemic risk. Consistent with the works of JONGHE (2010) and PAIS and STORK (2013), this is attributable to stronger interdependencies with the rest of the banking system, which is also a reason for their finding that correlations among equity returns are important to determine the degree of systemic distress in case of a failure. BALLA, ERGEN, and MIGUEIS (2014) propose a new measure to identify systemically important financial institutions which is derived from multivariate extreme value theory to capture the tail dependencies between stock returns. They find that size, measured by total assets, is a key predictor for a banks' vulnerability to the occurrence of a systemic crisis. In particular, they find that pairs of large institutions experience stronger asymptotic dependence. However, their method does not allow for the interpretation of a causal relationship between size and tail dependence, and further, it might reflect financial markets' perception of similarity rather than their economic exposure to systemic risk.

VALLASCAS and KEASEY (2012) focus on a sample of 153 listed European commercial banks from 1992 to 2008 since the integration process in Europe favors the growth of banks beyond national borders and the deregulation increases the scope for diversification. They observe the systemic context for large banks by investigating large banks' exposure to systemic events and their contribution to systemic risk. ${ }^{6}$ In line with JONGHE (2010) and KNAUP and WAGNER (2010), they find that certain bank characteristics such as an increase in non-traditional lending activities or higher leverage increase a bank's vulnerability to systemic shocks. Most importantly, the economic impact of pure size ${ }^{7}$

\footnotetext{
6 They define a bank's exposure to systemic risk by estimating a distance to default beta $\left(\beta_{D D_{i, t}}\right)$ that expresses how the default risk of bank i reacts to changes in banking system risk and a bank's contribution to systemic risk by estimating a contribution distance to default beta $\left(B_{C \_D D_{i, t}}\right)$ that measures the sensitivity of the distress of the banking system to changes in the default risk of bank $i$.

7 VAllascas and KeASEY (2012) distinguish between absolute (total assets) and systemic size (bank total assets relative to country GDP). While both variables significantly contribute to a banks' exposure to systemic risk, the economic effect of absolute size is dominant. However, when looking at the contribution to systemic risk rather than the exposure, the relative size appears to be more important.
} 
on a bank's exposure and contribution to systemic risk generally outreaches all other bank-specific control variables. This evidence supports the assumption that simply due to their size, large banks are a threat for financial stability, a result that holds in normal times as well as under extreme stress conditions. Hence, against this background, VALLASCAS and KEASEY (2012) argue that implementing a (country-specific) size-cap as a possible regulatory restriction might be beneficial for systemic stability, although the possible negative consequences of such a constraint and the issue of a potential trade-off are not part of their work.

GRAVELLE and LI (2013) propose a new market-based measure which they apply to a sample of Canadian, U.S., European and Asian banks in the Canadian banking market. They define systemic risk "as an event in which at least a certain fraction of financial institutions (...) crash simultaneously” (p. 2197) and measure an institution's (or a group of institutions) contribution to it. They capture idiosyncratic effects as well as institutions' exposure to common factors but eliminate this exposure to isolate the effects of an idiosyncratic shock from one institution to another. Their results are interesting in two ways. First, they observe that the largest crash dependence risk for Canadian institutions comes from other Canadian institutions and thus seems to be "home biased". Second, among the international institutions large U.S. banks (JPMorgan, Citigroup and Wells Fargo) in particular are the largest dependence risk factors to the Canadian banking sector. They conclude their analysis by arguing that size should not be considered as a proxy of systemic importance, a result that we put into question for two reasons. First, the three banks with the highest systemic importance are at the same time the three largest Canadian banks. Second, the U.S. banks posing the highest systemic risk to the Canadian banking industry were ranked top two, three and four in the U.S. (or top nine, ten and twenty-four globally) by the end of 2009 in terms of total assets. Against this background, it seems plausible to assume that the size of an institution is indeed a major determinant of systemic risk in the relevant market as GRAVELLE and LI (2013) do not relate their systemic importance measure to an institution's market share or other characteristics.

In this section, we find a plurality of empirical evidence in line with the results from theoretical network studies regarding the exposure of large banks to common shocks, as well as their contribution to systemic risk. We have reviewed ten studies, of which eight equally find that large banks have significantly higher systemic risk and that size is a key predictor for a banks' vulnerability to the occurrence of a systemic crisis. These studies use a variety of different approaches, as well as diverse sample compositions and periods that apparently conform to the necessary surrounding conditions and properties of the financial 
system, which make size one of the most important factors for systemic risk, as discovered by the theoretical models specified in Section 4.1. Furthermore, the relationship between size and systemic risk seems to be non-linear as the largest banks disproportionately contribute to overall risk. Again, banks focusing on traditional lending activities are found to be less exposed to systemic risk than diversified banks. Only two studies (GRAVELLE and LI, 2013; KNAUP and WAGNER, 2010) find different results but they should, in our view, be interpreted with caution due to several methodological differences and caveats, as described above.

\subsection{Empirical results from evolving standard techniques}

While the systemic risk measures used in the previous section vary, there is also a line of literature using more homogenous techniques. One of these is the socalled $\triangle$ CoVaR, initially proposed by ADRIAN and BRUNNERMEIER (2008), which captures the marginal contribution of a particular institution to the overall systemic risk. It compares the losses of the financial system when a specific financial institution experiences large losses to the losses of the system when the institution is in a normal state (CASTRO and FERRARI, 2014; WEIß and MÜHLniCKel, 2014). For example, BrunNERMEIER, Dong, and PAlia (2012) use $\triangle \mathrm{CoVaR}$ and the Systemic Expected Shortfall (SES) to analyze the contribution to systemic risk for a sample of listed bank holding companies in the U.S. over the period 1986 to 2008. They find that a bank's stock returns during the last financial crisis significantly decrease with bank size, and bank size is positively correlated with systemic risk. Even when controlling for several other bank characteristics, larger banks contribute more than proportionally to both measures of systemic risk. LópEz-ESPINOSA et al. (2013) and LóPEZ-EsPINOSA et al. (2012) also use $\triangle \mathrm{CoVaR}$ to empirically investigate which factors mainly determine a systemically important bank's contribution to systemic risk. They find that individual liquidity risk represents the main component of financial instability and that investment banking and international activities reinforce each other through loss spirals. In their samples, which are in both studies composed of large international banks only, neither absolute nor relative size can be identified as predictors of systemic risk, which could be due to the homogenous sample selection and does not necessarily imply that size per se is not a source of systemic risk. Further studies using $\triangle \mathrm{CoVaR}$ were conducted by CASTRO and FERRARI (2014) and ADRIAN and BRUNNERMEIER (2016). Both studies find that bank size clearly increases the systemic risk contribution of financial institutions. CASTRO and FERRARI (2014) further enhance $\Delta$ CoVaR and 
develop a test of significance to determine whether institutions can be ranked according to their systemic risk contribution. Applying their method to a sample of 26 large European banks, they find that only a few banks can be ranked on the basis of $\triangle \mathrm{CoVaR}$ but that a simple scaling of $\Delta \mathrm{CoVaR}$ with total assets increases the number of banks whose systemic importance dominates other banks'. They conclude that this result is due to the properties of $\Delta \mathrm{CoVaR}$ that attributes banks of different sizes the same systemic risk contribution if they are otherwise identical. Hence, without explicitly accounting for bank size and other characteristics, it is difficult to measure the effect of pure size on systemic risk with $\triangle$ CoVaR.

Other market-based measures frequently used are the Marginal Expected Shortfall (MES) or the Systemic Expected Shortfall (SES) proposed by ACHARYA et al. (2010). The MES is defined as the average return on a firm's stock in a defined period of time when the financial sector experienced its VaR\% lowest returns beyond the confidence level. The SES represents the expected amount of a bank's undercapitalization in a systemic crisis when the overall financial system is undercapitalized. ${ }^{8}$ Hence, compared to $\Delta$ CoVaR, the conditioning of the MES has been switched, and therefore, the MES captures an institution's exposure rather than its contribution to a systemic crisis (ACHARYA et al., 2010; BANulescu and Dumitrescu, 2015; Jonghe, DiePSTRATEN, and SCHEPENS, 2015; WEIß and MÜHLNICKEL, 2014). ACHARYA et al. (2017) show that the MES and SES are able to predict systemic risk during the recent crisis. Additionally, they find that the size in terms of total assets is significant in predicting realized SES during the crisis but loses part of its explanatory power when MES and leverage are included in the regression. Further, the top 6 institutions most contributing to the loss in market capitalization were also in the top 7 in terms of total assets, demonstrating that the contribution to financial sector capital deterioration is naturally tied to the size of the institution.

WEiß, BostAndzic, and NEUMANN (2014a) review several international crises to identify individual bank characteristics that determine an institution's exposure to systemic risk and whether these are persistent over time. They apply the MES and lower tail dependence (LTD) ${ }^{9}$ to a global sample of banks from

8 ACHARYA et al. (2017) differentiate between distress and a systemic crisis using MES to cover "moderately bad days" while using extreme value theory to show that SES is predicted by MES and leverage to estimate the effects during a real crisis.

9 As Weiß, BostANDZIC, and NEUMANN (2014a) note, their LTD is conceptually quite similar to the MES with the differences that (a) LTD considers the left tail of the joint distribution of the market and the individual institution instead of the marginal distribution of the market and (b) LTD captures extreme tails, while MES is based on moderate losses. 
different regions over six crises periods from 1994 (Mexico crisis) to 2008 (Lehman collapse). They find that, among other factors, bank size generally is not a powerful variable in explaining a bank's exposure to moderate systemic risk, with the latest crisis in 2007/2008 being the only exception. Looking at extreme systemic events, bank size is positively related to systemic risk only during the Mexican and Asian crises. Further and quite important regarding moderate systemic risk, size actually seems to lower banks' systemic risk exposure for most crises under investigation except the Lehman collapse. Looking at extreme systemic risk, size loses its explanatory power. They also perform their analysis on a subsample of large banks only (total assets above 50 billion USD) and verify that bank size is not a relevant and persistent driver of a bank's exposure to systemic risk. On the other hand, WEIß, NEUMANN, and BOSTANDZIC (2014b) use the same measures to examine a sample of 440 global bank mergers between 1991 and 2009 and state that the exposure of the combined bank (after the merger) to systemic risk is significantly larger than the sum of the acquirer's and the target's individual pre-merger systemic risk exposure. This in turn could be interpreted as further evidence that systemic risk disproportionately increases with an institution's size as already found by other studies using different methods (see, e.g., CACCIOLI, CATANACH, and FARMER, 2012; PuZANOva and DÜllmann, 2013; TARASHEV, TSATSAROnis, and Borio, 2016). Jonghe, DiEPSTRATEN, and SCHEPENS (2015) question that size and complexity have multiplicative or interaction effects and extend the previous literature by analyzing their joint and interactive impact on banks' MES. Looking at an international sample of listed banks from 1997-2011, they find that diversification benefits dominate for large banks. In particular, while absolute size always increases exposure to systemic risk, scope expansion and innovation into non-interest income activities significantly reduces risk for the largest banks above a certain size-threshold (in their case 964 million USD). This result is contrary to the findings of BAELE, JONGHE, and VANDER VENNET (2007), JONGHE (2010), KNAUP and WAGNER (2010), VALLASCAS and KEASEY (2012) and others and further is strongly dependent on institutional country characteristics (transparent information, concentration in the banking market and the value of a reputation of avoiding conflicts of interest for various stakeholders) since JONGHE, DiEPSTRATEN, and SCHEPENS (2015) also find that the benefits of diversification for large banks disappear when the information environment is non-transparent and asymmetric, corruption is higher and the market is highly concentrated.

Following the same intention as WEIß, BOSTANDZIC, and NEUMANN (2014a), LAEVEN, RATNOVSKI, and TONG (2014) also identify bank-specific factors that determine systemic risk. Nevertheless, their approach significantly differs, as they focus on the recent crisis only from July 2007 to December 2008 and use a 
slightly different measure for systemic risk, namely, SRISK. ${ }^{10}$ They find that the systemic risk contribution increases with bank size and is statistically and economically significantly higher for large banks with assets above 50 billion USD. A lower capital base, less stable funding or a high share of non-interest income further increases contribution to systemic risk. This last finding again indicates that revenue diversification may be beneficial from a microprudential perspective, while it seems to be detrimental from a macroprudential angle. BANUlESCU and Dumitrescu (2015) propose the Component Expected Shortfall (CES), ${ }^{11}$ to identify the contribution of each institution to the overall systemic risk. They find that risk is very concentrated since a significant amount of total risk can be attributed to a small number of firms and that these institutions are quite large in terms of market capitalization or total assets. Unfortunately, BANUlESCU and DUMITRESCU (2015) do not explicitly investigate whether size is a major determinant of CES or whether other institutional factors are responsible for the contribution of these particular firms to systemic risk.

In a later version, LAEVEN, RATNOVSKI, and TONG (2016) use $\triangle \mathrm{CoVaR}$ and SRISK to capture systemic risk for a sample of 339 publicly traded deposit-taking institutions from 32 countries with assets above 10 billion USD. As a first result, they find that both measures are highly correlated with bank size and that they also capture different aspects of systemic risk. Further, they find that, during the crisis, size per se was a main driver for standalone bank risk. This tendency also holds when looking at the impact of bank size on systemic risk. LAEVEN, RATNOVSKI, and TONG (2016) find strong evidence that bank size substantially increases the systemic risk contribution measured by either $\triangle \mathrm{CoVaR}$ or SRISK and that, unlike other bank characteristics, a higher capital ratio is particularly important for lowering the systemic risk for large banks. In a recent study, BucH, KRAUSE, and TONZER (2017) confirm these results for a sample of banks in the euro area from 2005-2013 also using the SRISK measure. A bank's contribution to systemic risk is significantly and robustly positively related, among other factors, to its (absolute as well as relative) size even after controlling for business model

10 SRISK, proposed by ACHARYA, ENGLE, and RICHARDSON (2012); ACHARYA et al. (2017) and BROWNLEES and ENGLE (2012, 2016)), represents the expected capital shortfall of a bank in case of a systemic event over a given time horizon and is a function of the bank's degree of leverage, size and MES. Hence, SRISK measures the contribution of a specific bank to the deterioration of capital in the financial system as a whole.

11 As mentioned by BANULESCU and DuMitresCU (2015), CES corresponds to the product of MES and the weight of the institution in the system and is by construction very similar to SRISK with the main difference that it does not require balance sheet data and no assumption is made about constancy of liabilities or leverage. 
characteristics, complexity, quality of the loan portfolio, liquidity risk or a dummy variable for banks assigned as globally systemically important.

Summing up the results of this section, the thirteen empirical studies in our sample using evolving standard techniques reassure the findings from Sections 4.1 and 4.2. Eight studies find size and systemic risk to be positively correlated. Systemic risk increases statistically and economically significantly with both absolute and relative size, even after controlling for business model characteristics, and seems to be naturally tied to the size of an institution and highly concentrated to a small number of large firms. Furthermore, several studies again find that larger banks contribute more than proportionally to systemic risk. Only two studies (LóPEZ-ESPINOSA et al., 2012, 2013) do not find size to be a relevant predictor for systemic risk, at least in their samples, which are composed only of large international banks. Three studies provide ambiguous evidence and indicate that the impact of bank size on systemic risk is not persistent over time or dependent on institutional country characteristics.

\section{Conclusions}

The aim of our paper was to provide a brief overview of the existing literature dealing with the contribution of large banks to systemic risk. To this end, we particularly focused on the literature that emerged during or after the last global financial crisis to take into account the plurality of methodical improvements that have been developed. Our literature sample contains thirty studies, of which a majority of sixteen studies (53\%) find that financial stability is negatively affected by large banks through a higher contribution to systemic risk or an increased exposure to common shocks. Nine studies (30\%) find that bank size is a major determinant for systemic risk if certain other conditions are met, while a minority of five studies (17\%) find that size per se is not a relevant factor in this context.

From a theoretical perspective, six out of the seven the studies reviewed in Section 4.1 argue that large banks are not necessarily a threat for financial stability. However, certain characteristics of a financial system, such as the degree of connectivity and the potential for contagious spillovers, might fundamentally change the importance of bank size and cause this determinant to become one of the most important factors for systemic risk. This hypothesis is verified by a considerable number of sixteen empirical studies in Sections 4.2 and 4.3 finding that against the background of the constitution of present-day real financial systems, a higher contribution to financial instability can indeed be attributed to pure size. This relationship is assumed to be non-linear, as 
systemic risk disproportionately increases with bank size, and the relationship is found in samples of different composition, for various periods and with different measures covering diverse aspects of systemic risk. This finding is important, since the work of KLEINOW et al. (2017) suggests that systemic risk assessments based on a single risk metric should be taken with caution, and the measures for exploring this important issue are still developing. However, it is important to mention that potential regulatory actions to address the problem of being "too big to fail" require a clear distinction between the determinants of systemic risk, but no common standard has evolved to separate the effects of pure size from other observable or even unobservable factors.

Nevertheless, structural developments in the aftermath of the last crisis should be critically reviewed. Specifically, research has shown that in highly interconnected financial networks, the size of institutions is clearly more dangerous, and the failure of a large bank has the potential to trigger a serious default cascade. In the context of ongoing globalization, this issue becomes increasingly important. The impact of size on systemic risk is also amplified in highly concentrated banking systems in which the largest banks are a multiple of the size of small banks. Reviewing the formation of larger and more complex (and hence non-transparent) institutions after the recent crisis and hypothesizing that consolidation among banks will proceed during the next few years indicated that this issue is far from being solved.

We believe that important lessons have been learned in the last few years to address the problem of "too big to fail". Several advances were made by regulators around the world to improve microprudential regulation of banks, as well as macroprudential regulation of the financial system as a whole. Other proposals, such as cutting the size of large banks, have not been implemented to date, as this would require the definition of an optimal bank size. This task might also become an interesting issue for further research along with the ongoing analysis on the determinants of large financial institutions' contribution to systemic risk if future analyses verify the results reviewed in our sample and if the recently established regulatory measures fail to serve their purpose.

\section{References}

Abreu, J. F. and M. A. Gulamhussen (2013): The Stock Market Reaction to the Public Announcement of a Supranational List of Too-Big-To-Fail Banks during the Financial Crisis, Journal of International Financial Markets, Institutions and Money 25, 49-72.

ACharYa, V. V. (2009): A Theory of Systemic Risk and Design of Prudential Bank Regulation, Journal of Financial Stability 5(3), 224-255. 
ACharya, V. V., R. F. Engle and M. RiChardson (2012): Capital Shortfall: A New Approach to Ranking and Regulating Systemic Risks, The American Economic Review 102(3), 59-64.

Acharya, V. V., L. H. Pedersen, T. Philippon and M. Richardson (2010): Measuring Systemic Risk, NYU Stern Working Papers.

Acharya, V. V., L. H. Pedersen, T. Philippon and M. Richardson (2017): Measuring Systemic Risk, Review of Financial Studies 30(1), 2-47.

Adrian, T. and M. K. Brunnermeier (2008): CoVaR., Federal Reserve Bank of New York Staff Reports 348.

AdriAn, T. and M. K. Brunnermeler (2016): CoVaR, American Economic Review 106(7), 1705-1741.

ARINAminPathy, N., S. KaPADIA and R. M. MAY (2012): Size and Complexity in Model Financial Systems, Proceedings of the National Academy of Sciences of the United States of America 109(45), 18338-18343.

Baele, L., O. D. Jonghe and R. VAnder Vennet (2007): Does the Stock Market Value Bank Diversification? Journal of Banking \& Finance 31(7), 1999-2023.

BALLA, E., I. ERGEN and M. Migueis (2014): Tail Dependence and Indicators of Systemic Risk for Large US Depositories, Journal of Financial Stability 15, 195-209.

Bandt, O. D. and P. Hartmann (2000): Systemic Risk: A Survey, ECB Working Paper 35.

BAnUlescu, G.-D. and E.-I. DumitresCu (2015): Which are the SIFIs?: A Component Expected Shortfall Approach to Systemic Risk, Journal of Banking \& Finance 50, 575-588.

BARTh, J. R. and C. Wihlborg (2016): Too Big to Fail and Too Big to Save: Dilemmas for Banking Reform, National Institute Economic Review 235(1), R27-R39.

BASEL COMMITTEE ON BANKING SUPERVISION (2013): Global systemically important banks: updated assessment methodology and the higher loss absorbency requirement.

Battiston, S., D. D. Gatti, M. Gallegati, B. Greenwald and J. E. Stiglitz (2012): Default Cascades: When Does Risk Diversification Increase Stability?, Journal of Financial Stability 8(3), 138-149.

Benoit, S., G. Colletaz and C. Hurlin (2013): A Theoretical and Empirical Comparison of Systemic Risk Measures: MES versus CoVaR.

Benoit, S., J.-E. Colliard, C. Hurlin and C. PÉrignon (2017): Where the Risks Lie: A Survey on Systemic Risk, Review of Finance 21(1), 109-152.

Bertay, A. C., A. Demirgüç-Kunt and H. Huizinga (2013): Do We Need Big Banks?: Evidence on Performance, Strategy and Market Discipline, Journal of Financial Intermediation 22(4), 532-558.

Bisias, D., M. Flood, A. W. Lo andS.Valavanis (2012): A Survey of Systemic Risk Analytics, Annual Review of Financial Economics 4(1), 255-296.

Bluhm, M. and J. P. Krahnen (2014): Systemic Risk in an Interconnected Banking System with Endogenous Asset Markets, Journal of Financial Stability 13, 75-94.

Bongini, P., L. Nieri and M. Pelagatti (2015): The Importance of Being Systemically Important Financial Institutions, Journal of Banking \& Finance 50, 562-574.

Boyd, J. H. and A. HeITZ (2016): The Social Costs and Benefits of Too-Big-To-Fail Banks: A "Bounding" Exercise, Journal of Banking \& Finance 68, 251-265.

BrownleEs, C. T. and R. F. Engle (2012): Volatility, correlation and tails for systemic risk measurement.

BrownleEs, C. T. and R. F. Engle (2016): SRISK: A Conditional Capital Shortfall Measure of Systemic Risk, Review of Financial Studies 30(1), 48-79.

Brunnermeier, M. K., G. Dong and D. Palia (2012): Banks' Non-Interest Income and Systemic Risk, Paper presented at the AFA 2012 Chicago Meeting. 
BuCH, C. M., T. KRAUSE and L. Tonzer (2017): Drivers of systemic risk: Do national and European perspectives differ? Deutsche Bundesbank Discussion Paper 09/2017.

CACCIOl, F., T. A. CATANACH and J. D. Farmer (2012): Heterogeneity, Correlations and Financial Contagion, Advances in Complex Systems 15 Suppl. No. 2, 1250058-1-1250058-15.

CASTRO, C. and S. FERRARI (2014): Measuring and Testing for the Systemically Important Financial Institutions, Journal of Empirical Finance 25, 1-14.

Cubillas, E., A. I. FeRnÁNDEZ and F. González (2017): How Credible Is a Too-Big-To-Fail Policy?: International Evidence from Market Discipline, Journal of Financial Intermediation 29, 46-67.

DAM, L. and M. KoETTER (2012): Bank Bailouts and Moral Hazard: Evidence from Germany, Review of Financial Studies 25(8), 2343-2380.

Danielsson, J. O. N., K. R. James, M. Valenzuela and I. Zer (2016): Can We Prove A Bank Guilty of Creating Systemic Risk?: A Minority Report, Journal of Money, Credit and Banking 48(4), 795-812.

DemiRgüç-Kunt, A. and H. HuIZIngA (2013): Are Banks Too Big to Fail or Too Big to Save?: International Evidence from Equity Prices and CDS Spreads, Journal of Banking \& Finance 37(3), 875-894.

Dermine, J. and D. SChoenmaker (2010): In Banking, Is Small Beautiful? Financial Markets, Institutions \& Instruments 19(1), 1-19.

Ellis, L., A. Haldane and F. Moshirian (2014): Systemic Risk, Governance and Global Financial Stability, Journal of Banking \& Finance 45, 175-181.

FINANCIAL STABILITY BOARD (2010): Reducing the moral hazard posed by systemically important financial institutions: FSB Recommendations and Time Lines.

FINANCIAL STABILITY BOARD (2014): Structural Banking Reforms. Cross-border consistencies and global financial stability implications: Report to G20 Leaders for the November 2014 Summit.

FreiXAS, X. and J.-C. RoChet (2013): Taming Systemically Important Financial Institutions, Journal of Money, Credit and Banking 45 Suppl. No. 1, 37-58.

GANDHI, P. and H. LUSTIG (2015): Size Anomalies in U.S. Bank Stock Returns, The Journal of Finance 70(2), 733-768.

Goldstein, M. and N. VÉRon (2011): Too Big to Fail: The Transatlantic Debate, Peterson Institute for International Economics Working Paper Series WP 11-2.

Gong, N. and K. D. Jones (2013): Bailouts, Monitoring, and Penalties: An Integrated Framework of Government Policies to Manage the Too-Big-To-Fail Problem, International Review of Finance 13(3), 299-325.

GravelLe, T. and F. LI (2013): Measuring Systemic Importance of Financial Institutions: An Extreme Value Theory Approach, Journal of Banking \& Finance 37(7), 2196-2209.

HE, F. and X. Chen (2016): Credit Networks and Systemic Risk of Chinese Local Financing Platforms: Too Central or Too Big to Fail?, Physica A: Statistical Mechanics and Its Applications 461, 158-170.

HeLweGE, J. (2010): Financial Firm Bankruptcy and Systemic Risk, Journal of International Financial Markets, Institutions and Money 20(1), 1-12.

Hovakimian, A., E. J. KANE and L. LAeVen (2012): Variation in Systemic Risk at US Banks during 1974-2010, NBER Working Paper No. 18043.

HuAnG, X., H. ZHOU AND H. ZHu (2012): Assessing the Systemic Risk of a Heterogeneous Portfolio of Banks during the Recent Financial Crisis, Journal of Financial Stability 8(3), 193-205.

INANOGLU, H., M. JACOBS, J. LIU and R. SiCKLES (2015): Analyzing Bank Efficiency: Are "Too-BigTo-Fail” Banks Efficient?, in: E. HAven, P. Molyneux, J. O. S. Wilson, S. Fedotov and 
M. Duygun (eds.) The Handbook of Post Crisis Financial Modeling. Palgrave Macmillan, Basingstoke, 110-146.

JoNGHE, O. D. (2010): Back to the Basics in Banking?: A Micro-Analysis of Banking System Stability, Journal of Financial Intermediation 19(3), 387-417.

Jonghe, O. D., M. Diepstraten and G. Schepens (2015): Banks' Size, Scope and Systemic Risk: What Role for Conflicts of Interest?, Journal of Banking \& Finance 61, S3-S13.

Kaufman, G. G. (2002): Too Big to Fail in Banking: What Remains?, The Quarterly Review of Economics and Finance 42(3), 426-436.

Kaufman, G. G. (2003): Too Big to Fail in U.S. Banking: Quo Vadis?

Kaufman, G. G. (2014): Too Big to Fail in Banking: What Does It Mean? Journal of Financial Stability 13, 214-223.

KeISTER, T. (2016): Bailouts and Financial Fragility, The Review of Economic Studies 83(2), 704-736. Kleinow, J., F. Moreira, S. Strobl and S. VÄHÄMAA (2017): Measuring Systemic Risk: A Comparison of Alternative Market-Based Approaches, Finance Research Letters 21, 40-46.

KNAUP, M. and W. WAGner (2010): Measuring the tail risks of banks, Swiss National Centre of Competence in Research on Trade Regulation Working Paper 2009/14.

KNot, K. H. W. and H. VAN Voorden (2013): Systemically Important Banks - Possible Options for Policy Makers, in: A. DOMBRET and O. Lucius (eds.) Stability of the Financial System. Illusion or Feasible Concept?. Edward Elgar Publishing, Cheltenham, 288-309.

KraUSE, A. and S. GIANSANTE (2012): Interbank Lending and the Spread of Bank Failures: A Network Model of Systemic Risk, Journal of Economic Behavior \& Organization 83(3), 583-608.

LAEVEn, L., L. RATNOvSKı and H. Tong (2014): Bank size and systemic risk, International Monetary Fund Staff Discussion Note 14/04.

Laeven, L., L. Ratnovski and H. Tong (2016): Bank Size, Capital, and Systemic Risk: Some International Evidence, Journal of Banking \& Finance 69 Suppl. 1, S25-S34.

LEADERS OF THE GROUP OF TWENTY (2009a): London summit - Leaders' statement: 2 April 2009. LEADERS OF THE GROUP OF TWENTY (2009b): Leaders' statement: The Pittsburgh summit: September 24-25, 2009.

López-Espinosa, G., A. Moreno, A. Rubia and L. Valderrama (2012): Short-Term Wholesale Funding and Systemic Risk: A Global CoVaR Approach, Journal of Banking \& Finance 36(12), 3150-3162.

López-Espinosa, G., A. Rubia, L. VAlderRama and M. Antón (2013): Good for One, Bad for All: Determinants of Individual versus Systemic Risk, Journal of Financial Stability 9(3), 287-299.

LU, J. and X. Hu (2014): Novel Three-Bank Model for Measuring the Systemic Importance of Commercial Banks, Economic Modelling 43, 238-246.

Mester, L. J. (2010): Scale Economies in Banking and Financial Regulatory Reform, The Region 24, 10-13.

Moenninghoff, S. C., S. Ongena and A. WieAndt (2015): The Perennial Challenge to Counter TooBig-To-Fail in Banking: Empirical Evidence from the New International Regulation Dealing with Global Systemically Important Banks, Journal of Banking \& Finance 61, 221-236.

MolyneuX, P., K. SCHAECK and T. M. ZHOU (2014): 'Too Systemically Important to Fail' in Banking - Evidence from Bank Mergers and Acquisitions, Journal of International Money and Finance 49, 258-282.

MuluineuX, A. (2014): Banking for the Public Good, International Review of Financial Analysis 36, 87-94.

NitschKA, T. (2016): Is There a Too-Big-To-Fail Discount in Excess Returns on German Banks' Stocks?, International Finance 19(3), 292-310. 
PAIS, A. and P. A. Stork (2013): Bank Size and Systemic Risk, European Financial Management 19(3), 429-451.

PoP, A. and D. POP (2009): Requiem for Market Discipline and the Specter of TBTF in Japanese Banking, The Quarterly Review of Economics and Finance 49(4), 1429-1459.

Puzanova, N. and K. Düllmann (2013): Systemic Risk Contributions: A Credit Portfolio Approach, Journal of Banking \& Finance 37(4), 1243-1257.

Rose, A. K. and T. WIELAdeK (2012): Too Big to Fail: Some Empirical Evidence on the Causes and Consequences of Public Banking Interventions in the UK, Journal of International Money and Finance 31(8), 2038-2051.

Segoviano, M. A. and C. Goddhart (2009): Banking Stability Measures, IMF Working Paper 09/4.

SiLva, W., H. KImURA and V. A. Sobreiro (2017): An Analysis of the Literature on Systemic Financial Risk: A Survey, Journal of Financial Stability 28, 91-114.

SMAGA, P. (2013): Assessing Involvement of Central Banks in Financial Stability, Center for Financial Stability Policy Paper.

Stern, G. H. and R. J. FeldMAN (2004): Too Big to Fail: The Hazards of Bank Bailouts. Brookings Institution Press, Washington, DC.

TARASHev, N., K. TSATSARONIS and C. Borio (2016): Risk Attribution Using the Shapley Value: Methodology and Policy Applications, Review of Finance 20(3), 1189-1213.

UEDA, K. and B. WEDER DI MAURo (2013): Quantifying Structural Subsidy Values for Systemically Important Financial Institutions, Journal of Banking \& Finance 37(10), 3830-3842.

Vallascas, F. and K. KeASEY (2012): Bank Resilience to Systemic Shocks and the Stability of Banking Systems: Small Is Beautiful, Journal of International Money and Finance 31(6), 1745-1776.

VANHOOSE, D. D. (2011): Systemic risks and macroprudential bank regulation: A critical appraisal, Networks Financial Institute at Indiana State University Policy Brief 2011-PB-04.

VLAHOVIĆ, A. (2014): Challenges to the Implementation of a New Framework for Safeguarding Financial Stability, Journal of Central Banking Theory and Practice 3(3), 19-52.

VöLZ, M. and M. Wedow (2011): Market Discipline and Too-Big-To-Fail in the CDS Market: Does Banks' Size Reduce Market Discipline?, Journal of Empirical Finance 18(2), 195-210.

WAGNER, W. (2010): Diversification at Financial Institutions and Systemic Crises, Journal of Financial Intermediation 19(3), 373-386.

WALTER, I. (2009): Economic Drivers of Structural Change in the Global Financial Services Industry, Long Range Planning 42(5-6), 588-613.

Weiß, G. N. F., D. BostandziC and S. Neumann (2014a): What Factors Drive Systemic Risk during International Financial Crises?, Journal of Banking \& Finance 41, 78-96.

WEIß, G. N. F. and J. MüHLNICKEL (2014): Why Do Some Insurers Become Systemically Relevant?, Journal of Financial Stability 13, 95-117.

Weiß, G. N. F., S. Neumann and D. Bostandzic (2014b): Systemic Risk and Bank Consolidation: International Evidence, Journal of Banking \& Finance 40, 165-181.

ZHou, C. (2009): Are Banks Too Big to Fail?: Measuring Systemic Importance of Financial Institutions, DNB Working Paper 232. 